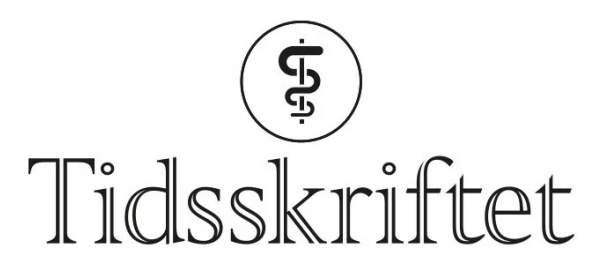

DEN NORSKE LEGEFORENING

\title{
Munntørrhet hos alvorlig syke og døende
}

\author{
KLINISK OVERSIKT
}

\section{SIRI FLAGESTAD KVALHEIM}

siri.flagestad.kvalheim@vlfk.no

Tannhelsetjenestens kompetansesenter Vestland

Hun har bidratt med idé, litteratursøk, utforming og utarbeiding av manus.

Siri Flagestad Kvalheim er ph.d. og tannlegespesialist i oral protetikk.

Forfatteren har fylt ut ICMJE-skjemaet og oppgir ingen interessekonflikter.

\section{ILEANA MIHAELA CUIDA MARTHINUSSEN}

Tannhelsetjenestens kompetansesenter Vestland

Universitetet i Bergen

Hun har bidratt med faglige råd og revisjon av manus.

Ileana Mihaela Cuida Marthinussen er spesialtannlege i kariologi, førsteamanuensis og klinikksjef.

Forfatteren har fylt ut ICMJE-skjemaet og oppgir ingen interessekonflikter.

\section{EINAR BERG}

Institutt for klinisk odontologi

Universitetet i Bergen

Han har bidratt med utforming og revisjon av manus.

Einar Berg er dr.odont. og professor emeritus i oral protetikk.

Forfatteren har fylt ut ICMJE-skjemaet og oppgir ingen interessekonflikter.

\section{GUNHILD VESTERHUS STRAND}

Institutt for klinisk odontologi

Universitetet i Bergen

Hun har bidratt med idé, faglig råd samt utforming og revisjon av manus.

Gunhild Vesterhus Strand er dr.odont. og professor i gerodontologi.

Forfatteren har fylt ut ICMJE-skjemaet og oppgir ingen interessekonflikter.

Munntørrhet er et betydelig problem for de fleste pasienter med alvorlig sykdom og palliativt behandlingsbehov. Hovedårsakene er bruk av legemidler, sykdommer og kreftbehandling, som ofte er assosiert med økende alder. Tilstanden kan føre til ubehag, smerte, dysfagi, taleproblemer, økt kariesaktivitet, dehydrering, 


\section{underernæring og tap av appetitt. Det finnes få produkter med evidensbasert effekt mot plagene. Et tilsynelatende banalt problem som munntørrhet kan derfor føre til forverring av sykdomsbildet og redusert livskvalitet.}

En studie fra 2016 av et representativt utvalg av norske sykehus og sykehjem viste at $25 \%$ manglet prosedyrer for munnstell hos alvorlig syke, og bare halvdelen av pleiepersonalet innså betydningen av munnstell (1). Blant institusjoner som hadde prosedyrer for munnstell, ble det benyttet mer enn 20 ulike produkter - mange uten noen dokumentert effekt eller sågar med potensielt skadelig effekt. For alvorlig syke pasienter i Norge kan det dermed bero på tilfeldigheter om man mottar munnstell og hvilke prosedyrer og produkter som da benyttes.

Når alvorlig syke pasienter mottar behandling og legemidler med svært plagsomme orale bivirkninger, tilbys ikke nødvendigvis helsehjelp i form av lindring av plagene (2). Orale infeksjoner øker risikoen for blant annet hjerte- og karsykdom, redusert kognitiv funksjon og pneumoni (3). Å få utført rutinemessig daglig munnstell ved alvorlig sykdom lindrer plager og reduserer denne risikoen (4).

I denne artikkelen belyses årsaker til og mulige behandlinger for munntørrhet. Oversikten er basert på egne studier i norske helseinstitusjoner, tilgjengelig litteratur, klinisk erfaring og eksisterende rutiner for munnstell hos alvorlig syke pasienter.

\section{Hva er munntørrhet?}

Friske individer produserer ca. o,6 liter saliva (spytt) i døgnet (5). Munntørrhet oppstår når spyttsekresjonen er mindre enn væsketapet fra munnhulen som følge av svelging, fordamping og absorpsjon gjennom slimhinnen i munnen (므). Xerostomi er pasientens subjektive oppfatning av munntørrhet, hyposalivasjon betegner objektiv og målbar munntørrhet. De to begrepene er ikke alltid sammenfallende. Salivasekresjon utenom måltider er vanligvis ca. $0,3 \mathrm{ml} / \mathrm{min}$. Mindre enn o, $1 \mathrm{ml} / \mathrm{min}$ defineres som hyposalivasjon. Xerostomi oppstår når sekresjonen reduseres til omtrent halvparten av normal mengde (7.), men kan også oppstå som følge av endret salivasammensetning (ㅁ). I slike tilfeller er spyttet ofte tyktflytende, seigt eller skummende.

\section{Saliva}

Saliva er en kompleks kroppsvæske med en rekke ulike egenskaper og funksjoner. Hovedinnholdet er vann (99,5\%), og i tillegg inneholder spytt elektrolytter og proteiner (9.). Væsken bidrar til å rense munnhulen. Ulike enzymer og proteiner i spyttet har antimikrobielle, antifungale og antivirale egenskaper.

Immunglobuliner, eksempelvis s-IgA, hemmer mikrobiell adhesjon og fremmer fagocytose og aggregering. Mucin danner en beskyttende hinne. Vekstfaktorer i saliva fremmer proliferasjon og sårtilheling (ㅇ). Spyttet har betydning for smak fordi det inneholder proteiner som bidrar til spalting av næringsstoffer og transport av smakssubstanser til smaksløkene (므). Spytt er også avgjørende for tygging, svelging, dannelse av bolus og for fordøyelsen, og dets bufferkapasitet spiller en viktig rolle for tannhelsen og for å opprettholde en balansert oral mikrobiota ( $\underline{8})$.

\section{Hvem rammes av munntørrhet?}


Munntørrhet forekommer i alle aldre, men kronisk og alvorlig grad av munntørrhet rammer spesielt eldre med polyfarmasi, kronisk og/eller terminal sykdom $(\underline{8}, \underline{11}, \underline{12})$. Tilstanden rammer kvinner oftere enn menn. Munntørrhet gjør at salivas rensende og smørende effekt uteblir. Er saliva tilnærmet fraværende, har ofte slimhinnene et læraktig utseende. En brennende og sviende følelse, sprekker, sår, smerte, nedsatt smakssans og taleproblemer forekommer ofte. Tilstanden $\emptyset$ ker mottakeligheten for infeksjoner $(\underline{8}, \underline{13})$ og gjør det vanskelig å svelge mat og drikke. Dette kan føre til underernæring, refluks, kvalme og dehydrering (14). Hos pasienter med lengre forventet levetid vil også karies med følgeskader kunne oppstå.

Tørrhet som strekker seg nedover i svelget og halsen, ofte i kombinasjon med candidainfeksjon, er en annen svært ubehagelig plage hos alvorlig syke og døende (144). Tilstanden oppdages ikke alltid ved rutinemessige undersøkelser. På grunn av generell svekkelse kan pasienten ha problemer med å formidle sine symptomer. Med munntørrhet og orale infeksjoner følger ofte halitosis - dårlig ånde - som kan virke frastøtende og redusere pasientens selvrespekt og verdighet. En tilsynelatende bagatellmessig tilstand som munntørrhet vil dermed kunne gi betydelig forverring av pasientens fysiske og psykiske helse og velvære.

\section{Årsaker}

Nedsatt sekresjon kan skyldes permanent strukturell endring av spyttkjertlene som følge av stråling, immunterapi eller autoimmune lidelser, eller patofysiologiske endringer i spyttkjertlene som følge av endokrine forstyrrelser $(\underline{8}, 15)$. Andre tilstander kan være forbigående, som sialolithiasis (spyttkjertelstein), dehydrering, angst og depresjon (16). Det finnes ikke spesifikke kliniske tegn som kan skille mellom ulike årsaker til munntørrhet (ㅁ).

Den vanligste årsaken til munntørrhet er bieffekter av behandling og legemidler som påvirker spyttrefleksen på ulike steder i sentralnervesystemet og/eller på reseptornivå i spyttkjertlene (무). Blant kreftpasienter er rundt 80 \% plaget av munntørrhet (17-19.). Mer enn 150 virkestoff påvirker spyttkjertelfunksjonen (므). Polyfarmasi $\emptyset$ ker prevalensen ytterligere $(\underline{16}, \underline{21})$. Opioide analgetika, sedativer, antidepressiver, anxiolytika, nevroleptika og antikolinergika som brukes hyppig i palliativ behandling, spesielt til terminale pasienter, gir alle munntørrhet $(\underline{8}, \underline{20})$. Hos palliative pasienter kan dessuten lavt væskeinntak, feber og medisinering påvirke reguleringen av salt-væske-balansen og føre til dehydrering. For alvorlig syke pasienter forsterkes ofte munntørrheten av munnpusting, skadet eller veldig tynn munnslimhinne, som kan øke væskeabsorpsjon, og skadede eller manglende spyttkjertler (C. Dawes, personlig meddelelse).

\section{Behandling}

\section{MUNNSTELL}

Munnstell hos alvorlig syke og døende skal inkludere kartlegging og diagnostisering av munntørrhet, smøring av lepper, rengjøring av tenner, rensing av slimhinner og fukting (르). Tenner rengjøres med myk børste. Tannkrem med natriumlaurylsulfat bør unngås, fordi denne kan virke uttørrende på slimhinnene (23). Slimhinner rengjøres med fysiologisk saltvann, eventuelt 0,5\% hydrogenperoksid. Påføring av 17 \% glyseroloppløsning kan benyttes som fuktemiddel. Løsningen lindrer munntørrhet, men på grunn av kortvarig effekt må den påføres hyppig (204.). Hvilke produkt/tiltak som virker lindrende, varierer med art og grad av munntørrhet samt pasientens preferanse. På svært tørre slimhinner kan produkter med høy viskositet virke klebrig og ubehagelig. Kvalme forekommer ofte hos 
pasienter i lindrende behandling. Produkter med mild smak og behagelig konsistens er derfor viktig. Siden symptomene og preferansene varierer, bør pasientene forsøke ulike typer $(\underline{2}, \underline{24})$.

\section{SALIVASUBSTITUTTER}

Det finnes en rekke salivasubstitutter - skyllemidler, gel, spray - som hevdes å motvirke munntørrhet. Ofte etterligner de spyttets utseende og flyteegenskaper, men har verken tilsvarende enzymatiske, antimikrobielle, antifungale eller antivirale egenskaper. De har heller ikke spyttets fysiske egenskaper (므). Per i dag finnes det ingen sterk vitenskapelig evidens for at noen av produktene på markedet gir effektiv lindring mot munntørrhet (므).

GLYSEROL

Glyserol i ulike vandige konsentrasjoner har vært det mest brukte produktet til munnstell og munntørrhet i Norge siden 1950-årene. Anbefalingene for glyserolløsninger er motstridende. I enkelte land frarådes bruken, fordi den hevdes å virke uttørrende heller enn fuktgivende. I Norge anbefales en $17 \%$ oppløsning av glyserol i vann. Anbefalingen på helsebiblioteket.no har blitt laget på grunnlag av empiri og tilgjengelig litteratur og er det nærmeste man kommer en nasjonal retningslinje (2ㅡ). Glyserolløsningen gir god umiddelbar lindring, men effekten forsvinner etter kort tid (24). Langtidsvirkningene av slik glyserolkonsentrasjon på slimhinnene er ukjent, men det synes usannsynlig at kortvarig bruk skulle gi særlige problemer. Glyserol blir imidlertid også brukt ufortynnet på orale slimhinner i noen norske helseinstitusjoner (1). Dette kan gi stort ubehag og betydelig forverring av munntørrheten. Skal glyserolløsning benyttes, må den blandes med vann i forholdet 1: 4 og påføres hyppig (24).

STIMULERING AV SALIVASEKRESJON

Spyttsekresjonen kan økes ved bruk av tyggegummi, pastiller og ved bruk av eple-, sitroneller askorbinsyre ( $\underline{16})$. For palliative pasienter med hyposalivasjon kan det være vanskelig å få løst opp pastiller. Tyggegummi er ofte uegnet på grunn av manglende tyggekraft (묘).

Pilokarpin er en muskarinreseptoragonist som øker sekresjon fra eksokrine kjertler og kan gi effektiv behandling mot xerostomi med dosering på minst 20 mg per dag (25). Bruken innebærer imidlertid uønskede bieffekter som svetting, hodepine, vannlating og

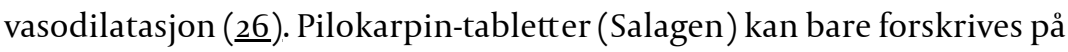
godkjenningsfritak. En ikke-godkjent indikasjon, som praktiseres i flere land, er pilokarpin-øyedråper $2 \%$ i munnen, 3-5 dråper 2-5 ganger daglig. Dette kan gi en god, men kortvarig effekt (207.). Medikamenter som stimulerer sekresjon, har imidlertid kun effekt hos pasienter der spyttkjertlene fortsatt har noen grad av funksjon.

\section{KUNSTIG HYDRERING}

Behandling av dehydrering vil kunne redusere plagene med munntørrhet (묘). Kunstig hydrering er væske gitt intravenøst, subkutant, dermalt, rektalt eller som en komponent av enteral ernæring eller parenteral ernæring. Hos palliative pasienter er kunstig hydrering utfordrende med tanke på fysiske faktorer, som fare for væskeansamling og lungeødem, men også av moralske, etiske og kulturelle grunner. Seponering av væske og ernæring hos døende pasienter diskuteres i litteraturen (209). Tilførsel av væske vil kunne forebygge nyresvikt og delirium samt gi bedre effekt av medikamenter. Motargumenter handler om at man bør unngå uheldig væskeansamling, at pasienten bør få slippe kateter og at man bør fokusere på forestående død. I hvilken grad tilførsel av væske reduserer tørrhet og tørste, er usikkert (30). At munnstell kan lindre munntørrhet, er et argument som blir brukt mot å gi væske. En forutsetning er da at munnstellet blir gjennomført.

\section{Konklusjon}

De fleste alvorlig syke og døende pasienter er sterkt plaget av munntørrhet. Produkter mot tilstanden er lite effektive, men godt renhold og hyppig fukting kan lindre plagene.

Helsevesenet må rutinemessig inkludere munnstell ved innleggelse, på lik linje med 
Artikkelen er fagfellevurdert.

\section{LITTERATUR}

1. Kvalheim SF, Strand GV, Husebø BS et al. End-of-life palliative oral care in Norwegian health institutions. An exploratory study. Gerodontology 2016; 33: 522-9. [PubMed][CrossRef]

2. Furness S, Worthington HV, Bryan G et al. Interventions for the management of dry mouth: topical therapies. Cochrane Database Syst Rev 2011; 12: CDoo8934. [PubMed][CrossRef]

3. Sanz M, Marco Del Castillo A, Jepsen S et al. Periodontitis and cardiovascular diseases: Consensus report. J Clin Periodontol 2020; 47: 268-88. [PubMed][CrossRef]

4. Gil-Montoya JA, de Mello AL, Barrios R et al. Oral health in the elderly patient and its impact on general well-being: a nonsystematic review. Clin Interv Aging 2015; 10: 461-7. [PubMed][CrossRef]

5. Watanabe S, Dawes C. The effects of different foods and concentrations of citric acid on the flow rate of whole saliva in man. Arch Oral Biol 1988; 33:1-5. [PubMed][CrossRef]

6. Dawes C. How much saliva is enough for avoidance of xerostomia? Caries Res 2004; 38: 236-40. [PubMed][CrossRef]

7. Edgar M, O’Mullane D, Dawes C. Saliva and oral health. 3. utg. London: British Dental Association, 2004 .

8. Pedersen AML, Sørensen CE, Proctor GB et al. Salivary secretion in health and disease. J Oral Rehabil 2018; 45: 730-46. [PubMed][CrossRef]

9. Edgar M, O’Mullane D, Dawes C. Saliva and oral health. 4. utg. London: British Dental Association, 2012.

10. Çelebioğlu HY, Lee S, Chronakis IS. Interactions of salivary mucins and saliva with food proteins: a review. Crit Rev Food Sci Nutr 2020; 60: 64-83. [PubMed][CrossRef]

11. Kaasa S, Loge JH. red. Palliasjon. Nordisk lærebok. 3. utg. Oslo: Gyldendal Akademisk, 2016.

12. Venkatasalu MR, Murang ZR, Ramasamy DTR et al. Oral health problems among palliative and terminally ill patients: an integrated systematic review. BMC Oral Health 2020; 20: 79. [PubMed] [CrossRef]

13. Sjögren P, Wårdh I, Zimmerman M et al. Oral Care and Mortality in Older Adults with Pneumonia in Hospitals or Nursing Homes: Systematic Review and Meta-Analysis. J Am Geriatr Soc 2016; 64: 210915. [PubMed][CrossRef]

14. Sweeney MP, Bagg J, Baxter WP et al. Oral disease in terminally ill cancer patients with xerostomia. Oral Oncol 1998; 34: 123-6. [PubMed][CrossRef]

15. Lacouture M, Sibaud V. Toxic Side Effects of Targeted Therapies and Immunotherapies Affecting the Skin, Oral Mucosa, Hair, and Nails. Am J Clin Dermatol 2018; 19 (suppl 1):31-9. [PubMed][CrossRef]

16. Carpenter G. red. Dry Mouth - A Clinical Guide on Causes, Effects and Treatments. Berlin: Springer, 2015.

17. Jensen SB, Pedersen AM, Vissink A et al. A systematic review of salivary gland hypofunction and xerostomia induced by cancer therapies: prevalence, severity and impact on quality of life. Support Care Cancer 2010; 18: 1039-6o. [PubMed][CrossRef]

18. Davies A, Bagg J, Laverty D et al. Salivary gland dysfunction ('dry mouth') in patients with cancer: a consensus statement. Eur J Cancer Care (Engl) 2010; 19: 172-7. [PubMed][CrossRef]

19. Wilberg P, Hjermstad MJ, Ottesen S et al. Oral health is an important issue in end-of-life cancer care. Support Care Cancer 2012; 20: 3115-22. [PubMed][CrossRef]

20. Wolff A, Joshi RK, Ekström J et al. A Guide to Medications Inducing Salivary Gland Dysfunction, Xerostomia, and Subjective Sialorrhea: A Systematic Review Sponsored by the World Workshop on Oral Medicine VI. Drugs R D 2017; 17: 1-28. [PubMed][CrossRef]

21. Närhi TO, Meurman JH, Ainamo A et al. Association between salivary flow rate and the use of systemic medication among 76-, 81-, and 86-year-old inhabitants in Helsinki, Finland. J Dent Res 1992; 71:1875-8o. [PubMed][CrossRef] 
22. Helse Bergen. Munnstell til voksne pasienter. Helsebiblioteket 3.11.2016.

https://www.helsebiblioteket.no/fagprosedyrer/ferdige/munnstell-til-voksne-pasienter Lest 5.1.2022.

23. Herlofson BB, Barkvoll P. Desquamative effect of sodium lauryl sulfate on oral mucosa. A preliminary study. Acta Odontol Scand 1993; 51:39-43. [PubMed][CrossRef]

24. Kvalheim SF, Marthinussen MC, Haugen DF et al. Randomized controlled trial of the effectiveness of three different oral moisturizers in palliative care patients. Eur J Oral Sci 2019; 127:523-30. [PubMed] [CrossRef]

25. Ramos-Casals M, Brito-Zerón P, Bombardieri S et al. EULAR recommendations for the management of Sjögren's syndrome with topical and systemic therapies. Ann Rheum Dis 2020; 79:318. [PubMed][CrossRef]

26. Davies AN, Thompson J. Parasympathomimetic drugs for the treatment of salivary gland dysfunction due to radiotherapy. Cochrane Database Syst Rev 2015; 10: CDoo3782. [PubMed]

27. Pilokarpin øyedråper til peroral bruk. RELIS 10.10.2016.

https://relis.no/sporsmal_og_svar/relisdb/3-11146 Lest 5.1.2022.

28. Burge FI. Dehydration symptoms of palliative care cancer patients. J Pain Symptom Manage 1993; 8: 454-64. [PubMed][CrossRef]

29. Strand AMR, Berg SF. Skal døende pasienter få væske og ernæring? Tidsskr Nor Legeforen 2019; 139. doi: 10.4045/tidsskr.18.0527. [PubMed][CrossRef]

30. Hui D, Dev R, Bruera E. The last days of life: symptom burden and impact on nutrition and hydration in cancer patients. Curr Opin Support Palliat Care 2015; 9:346-54. [PubMed][CrossRef]

Publisert: 7. februar 2022. Tidsskr Nor Legeforen. DOI: 10.4045/tidsskr.21.0232

Mottatt 22.3.2021, første revisjon innsendt 3.9.2021, godkjent 5.1.2022.

Publisert under åpen tilgang CC BY-ND. Lastet ned fra tidsskriftet.no 26. april 2023. 